\title{
The Interpretations of the Impact of Military Change on the International System
}

This article presents a theoretical approach of analysis and estimate of the influence of military change on international relations, as well as the interpretations of the impact of military change on international systems during various historical periods. The first part of the paper defines the term of the fundamental military change and the cycle of the fundamental military change in the international system; it also presents some insights of the offense-defence balance theory with the estimate of the impact of military change on international relations. The second part of the article describes various cases of the influence of fundamental military changes on the international system until the invention of the nuclear weapon (the revolutions of artillery, firearms and naval warfare from the $15^{\text {th }}$ until the $17^{\text {th }} \mathrm{c}$.). The chapter on the nuclear era provides an analysis about the role of military changes during and after the Cold War, i.e., in the contemporary international system. This article explains that until the invention of the nuclear weapon, fundamental military changes could determine the survival of a state and could provide it with exceptional opportunities to establish its power over other states. Meanwhile, during the nuclear era the impact of military transformations became much more subtle. It is claimed that during the Cold War military changes played the role of balancing the bipolar international system, whereas, after the Cold War the influence of such changes became destabilizing.

\section{Introduction}

The debates over the significance of military change to warfare (the forms and means of warfare) and to the international relations after the end of the Cold War became very popular after the US won a quick victory in the first Persian Gulf War in 1991, which was also linked with the effective use of precision-guided munitions in the conventional war ${ }^{1}$. The leaders of the US military community and some American academics began to interpret this as a consequence of the revolution in military affairs. This estimate became a starting point for Americans in renewing their plans for military development between the years 1996-1997. Besides, the maintenance of the American military power began to be associated namely with the revolution in military affairs.

\footnotetext{
${ }^{*}$ Karolis Aleksa is a PhD candidate, Institute of International Relations and Political Science, University of Vilnius. Address: Vokiečių 10, LT-01130 Vilnius, Lithuania, tel. +370-5-2514130 - karolisaleksa@hotmail. com

${ }^{1}$ It became possible due to the adjustment of informational technologies to the military needs.
} 
According to George W. Bush, who finished his term of presidential office in January 2009, "America has, and intends to keep, military strengths beyond challenge, thereby, making the destabilizing arms races of other eras pointless $[\ldots .]^{\prime \prime 2}$.

This so-called revolution in military affairs, however, gave rise to live discussions among the US defence community members themselves, which have become extremely sceptical of the US military transformation some time after the operations in Afghanistan and Iraq. There were some considerations that this transformation had stipulated the excessive belief of the US political and military leaders in the advantages of military advance as the means per se, solving the strategic political problems. ${ }^{3}$ Among sceptical estimations of the US military transformation there were some thoughts that military transformations, advocated and launched by the US are one-sided, i.e. the conventional forces are being developed in defiance of the most plausible threats. ${ }^{4}$

Debates on estimates of the American military progress have also given rise to a new wave of interest in the studies of war history and political sociolo$\mathrm{gy}^{5}$, which analyse the influence of military change on the development of state and interstate relationships. The question of the influence of military change on international relations is one of the more significant ones analysed by the representatives from the fields of war history and international relations. The research of the influence of military change on international relations is challenging and continuously raises discussions in various academic circles due to several reasons: firstly, it is not easy to define military change as a phenomenon itself. It is important to note that there have been ongoing attempts to define the term of military change and to analyse its impact in the state interior and transnational context since the middle of the $20^{\text {th }}$ century. Secondly, the estimation that distinguishes the influence of military change is analytically complicated. The military change does not affect international relations as an isolated factor - the recognition of the significance of military change by political leaders (political context), its acceptance among the international community (cultural context), and capacity to gain it (economical context) - can all be considered as its composite parts. The complexity of potential factors of the impact, and their mutual interaction, certainly burden the efforts to provide an exclusive (and thorough) assessment of the influence of military change on international relations. On the other hand, the interdisciplinary of the phenomenon bears new ideas and interpretations that render a huge surplus value in understanding the logic of the interstate interaction.

\footnotetext{
${ }^{2}$ President Bush Delivers Graduation Speech at West Point, 2002 June 1, http://ics.leeds.ac.uk/papers/vp01.cfm?outfit=pmt\&folder=339\&paper=380, 10042009.

${ }^{3}$ Gray C.S, Transformation and Strategic Surprise, Strategic Studies Institute, U.S. Army War College, April 2005, http://www.strategicstudiesinstitute.army.mil/pdffiles/PUB602.pdf, 25022008.

${ }^{4}$ See: Kagan F.W., Finding the Target: The Transformation of American Military Policy, New York, London: Encounter Books, 2006, p. 200-201.

${ }^{5}$ Especially in the circles of the American academic community, which seek to understand the significance of the contemporary military transformation.
} 
Taking into consideration intensive academic discussions on the influence of the US military progress on warfare, interstate relations as well as interdisciplinary controversies, this article seeks to present a theoretical approach of analysis and assessment of the influence of military change on international relations as well as the interpretations of the impact of military change on the international systems during various historical periods. Accordingly, the first part of the article defines fundamental military change and the relationship between fundamental military change and the international system; it also provides a presentation of the insights of the offense-defence balance theory linked with the estimates of the influence of military change on international relations. Meanwhile, the second part of this paper describes the interpretations of the influence of military changes on international relations during three different periods: the Middle Ages and Modern times; the Cold War period; and the contemporary international relations.

\section{The relationship between fundamental military change and international system: theoretical approach}

\subsection{The concept of fundamental military change}

Geoffrey Parker holds that the success of the Western nations in creating the first true global empires between 1500 and 1750 depended namely on the enhanced capabilities to wage war, which is defined as the military revolution. ${ }^{6}$ Meanwhile, the apologists of the contemporary military revolution might be disappointed with Colin S. Gray's statement that the Serbian campaign of 1999 and the Afghanistan campaign of 2001-2002 were not as successful as the forefront states of the military revolution would expect. ${ }^{7}$ These two examples simply prove that military changes create a diverse impact on the international environment, however, in order to assess the diversity of such impact it is necessary to agree upon the content of the fundamental military change concept.

The definition of the fundamental military change in the Western academic literature generally involves the concepts of military transformation, revolution in military affairs, military revolution, and military-technical revolution. The concept of the military revolution is distinguished from other concepts by the fact that it implies more than military change per se. The military revolution is a part (or an outcome) of the social and political process, which changes the image of state and society as well as the image of the international community (e.g. the birth of a modern State in the $16^{\text {th }}-17^{\text {th }}$ centuries, the Great French Re-

\footnotetext{
${ }^{6}$ Parker G., The Military Revolution: Military Innovation and the rise of the West, 1500-1800, Cambridge: Cambridge University Press, 1999, p. 4.

${ }^{7}$ Gray C. S., Another Bloody Century: Future Warfare, London: Phoenix, 2005, p. 101-102.
} 
volution and the Industrial Revolution). However, the concepts of revolution in military affairs, military transformation, and military-technical revolution specifically refer to changes in the field of war-waging (warfare).

The paradigm of the discussions about the military revolution emerged during the debates of Western historians about the importance of military change and its consequences in early modern times. The studies of Michael Roberts, Geoffrey Parker, Clifford J. Rogers and Jeremy Black helped to define the main landmarks of these debates. In the article The Military Revolution, 1560-1660, Michael Roberts was the first to publish his insights of the military revolution initiated by the Netherlands and Sweden in 1560-1660, noting the essential aspects of this revolution: 1) tactical revolution (replacement of enormous squares of pikemen with linear formation of smaller units dominated by soldiers who use firearms); 2) strategic revolution (due to the introduced military training the permanent forces were capable of using different strategies during battles and wars); 3) the significant increase of the number of military force necessary for realizing new strategies of battles and wars; 4) the impact on society and state. ${ }^{8}$ This study by Michael Roberts prompted the appearance of other historical studies on the subject of military revolutions. Geoffrey Parker, in his study, argued with Michael Roberts regarding the true founders and the origin of military revolution; according to Geoffrey Parker, the aspects of military revolution analyzed by Michael Roberts could be envisaged some time earlier in the Renaissance Italy and in Habsburgian Spain. Meanwhile the studies of Clifford J. Rogers and Jeremy Black drew attention to the military revolutions of other historical periods. Clifford J. Rogers maintained that during the Hundred Years' War (1337-1453) one can distinguish two essential military changes (the revolutions of the infantry and the artillery), which essentially changed warfare and could be compared to the military revolution analysed by Michael Roberts and Geoffrey Parker. ${ }^{9}$ Meanwhile, Jeremy Black in his study maintained that the military revolution of 1560-1660, distinguished by Michael Roberts, should be considered only as relative and limited military change among other fundamental military changes. According to Jeremy Black, the fundamental military change emerged namely after 1660 and continued until $1720 .^{10}$

The above mentioned historians' studies are just a few examples of the increased number of such studies. ${ }^{11}$ The historical estimations regarding the

\footnotetext{
${ }^{8}$ Roberts M., "The Military Revolution, 1560-1660" in Rogers C. J., ed., The Military Revolution Debate: Readings on the Military Transformation of Early Modern Europe, Colorado: Westview Press, 1995, p. 13-29.

${ }^{9}$ Ibid., p. 56.

${ }^{10}$ Black J., "A Military Revolution? A 1660-1792 Perspective" in Rogers C.J., ed., The Military Revolution Debate: Readings on the Military Transformation of Early Modern Europe, Colorado: Westview Press, 1995, p. 97.

${ }^{11}$ The studies of John A. Lynn, Colin Jones, Thomas F. Arnold, David A. Parrot, Simon Adams, I. A. A. Thompson, John F.Guilmartin, Jr, in: Rogers C. J., ed., The Military Revolution Debate: Readings on the Military Transformation of Early Modern Europe, Colorado: Westview Press, 1995.
} 
origin and the scale of the fundamental military change, as well as its impact on warfare and the international system always depend on the availability of historical sources, and also of course on the interpretation of these sources. However, such historical studies lack an attempt to seek a common consensus on the key elements of military change as a phenomenon which could certainly bring more light into historical discussions.

However, the definition of the fundamental military change did not emerge from the discussions among war historians; it emerged from the contemporary interdisciplinary debates among the Western theoreticians of strategic thought ${ }^{12}$ (war historians also actively participated in these discussions ${ }^{13}$ ). The idea of the contemporary military revolution, which after the first Persian Gulf War in 1991 fascinated some defence planners from the US, prompted the initiation of the research related to the historical military revolutions and thus more profound interpretations and theorizing about the concept of fundamental military changes.

In one of such studies Richard O. Hundley tried to define the term of the revolution in military affairs, maintaining that it marks a paradigmic break in the nature and execution of military operations which:

Make one or more core competencies ${ }^{14}$ of a dominant state ${ }^{15}$ out-of-date or unimportant;

Create one or more core competencies in the new dimensions of warfare;

Or the first two cases taken together.

\footnotetext{
${ }^{12}$ See: McKitrick J., Blackwell J., Littlepage F., Kraus G., Blanchfield R., Hill D., "The Revolution in Military Affairs", The Professional Journal of the United States Air Force, http://www.airpower.maxwell. af.mil/airchronicles/battle/chp3.html, 2509 2008.; Vickers M.G., Martinage R. C., The Revolution in War, Center for Strategic and Budgetary Assessments, December 2004, http://www.csbaonline.org/4Publications/ Archive/R.20041201.RevInWar/R.20041201.RevInWar.pdf, 2009 2008.; Metz S., Kievit J., Strategy and the Revolution in Military Affairs: From Theory to Policy, Strategic Studies Institute, 1995, http://www. au.af.mil/au/awc/awcgate/ssi/stratrma.pdf, 2009 2008.; Goldman E. O., Andres R. B., "Systemic Effects of Military Innovation and Diffusion”, Security Studies, Summer 1999, vol. 8, no. 4, p. 79-125, http://www. au.af.mil/au/awc/awcgate/innovation/jciss/syst.htm, 1002 2009.; Hawkins C. F., Brinkerhoff J. R., Horowitz S. A., A Historical Perspective on Military Transformation, http://www.herolibrary.org/transform.htm, 10 05 2009.; Isaacson J. A., Layne C., Arquilla J., Predicting Military Innovation, Arroyo Center, 1999, http:// www.rand.org/pubs/documented_briefings/2007/DB242.pdf, 10022009.

${ }^{13}$ Black J., "The Revolution in Military Affairs: The Historian's Perspective", Journal of Military and Strategic Studies, Winter 2006/07, Vol. 9, Issue 2, http://www.jmss.org/2007/2007winter/articles/black_contdefense.pdf, 20082008.

${ }^{14}$ Core competence, according to the definition by Richard O. Hundley, is a fundamental ability that provides for a set of military capabilities (e.g., the competence of the US Air Force is a capacity to attack moving targets on land with an exceptional precision).

${ }^{15}$ A dominant state is a state which possesses a dominating set of capabilities in an area of military operations.
} 
Table 1. Examples of means which prompted fundamental changes in military affairs ${ }^{16}$

\begin{tabular}{|l|l|l|}
\hline \multicolumn{1}{|c|}{$\begin{array}{c}\text { Revolution } \\
\text { in the military } \\
\text { affairs }\end{array}$} & Paradigmatic break & Core competency affected \\
\hline Machine gun & $\begin{array}{l}\text { Created a new tactical } \\
\text { level model for land } \\
\text { warfare }\end{array}$ & $\begin{array}{l}\text { Ability to manoeuvre massed } \\
\text { infantry forces in the open } \\
\text { space (rendered obsolete) }\end{array}$ \\
\hline $\begin{array}{l}\text { Intercontinental bal- } \\
\text { listic missiles }\end{array}$ & $\begin{array}{l}\text { Created a new dimen- } \\
\text { sion of warfare (inter- } \\
\text { continental strategic } \\
\text { warfare) }\end{array}$ & $\begin{array}{l}\text { Accurate long-range missiles } \\
\text { carrying nuclear warheads } \\
\text { (a new core competency) }\end{array}$ \\
\hline
\end{tabular}

For example, the invention of an automatic gun enabled a complete change of the tactical level of land warfare: free manoeuvres with infantry forces in order to break the defence of the enemy became impossible because of potentially huge casualties, and therefore an inescapable defeat in the battle. Thus, a slightly larger superiority of having more infantry than the enemy became unimportant due to the growing defensive power with the help of an automatic gun. Meanwhile, the invention of intercontinental ballistic missiles led to a new dimension of warfare, which did not require the physical dislocation of troops or sending them to the territory of the enemy. (See Table 1)

In order to identify the fundamental military change, one needs to clearly define the cycle of such change. The identification of the fundamental military change cycle enables one to determine the existence of such change per se, which means that it is possible to draw fairly reliable conclusions on the influence of such change on warfare and the international environment. The identification of the fundamental military change becomes possible only when the change reaches the phase of exploitation. (See Picture 1)

\footnotetext{
${ }^{16}$ Hundley R. O., Past Revolutions. Future Transformations. What can the history of revolution in military affairs tell us about transforming the U.S. military?, National Defense Research Institute, RAND, 1999, http://www.rand.org/pubs/monograph_reports/2007/MR1029.pdf, 15092008.
} 


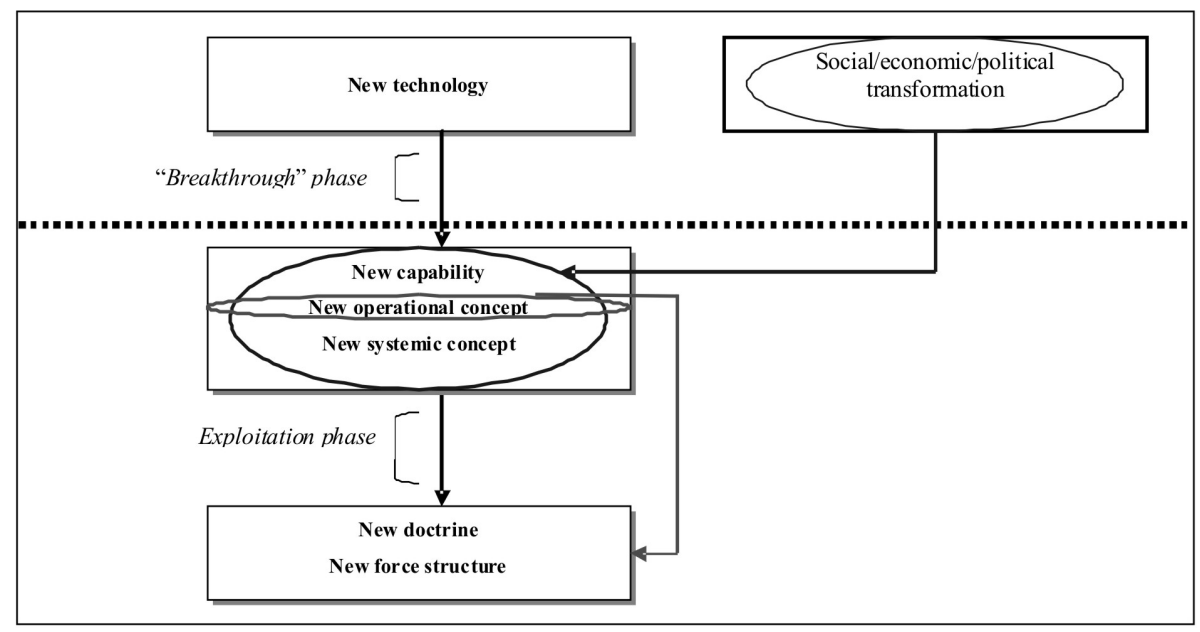

Figure 1. The cycle of the revolution in military affairs ${ }^{17}$

Generally, the fundamental military change begins with the invention of a new technology (e.g., a big bow, firearm or ballistic missiles), with the social/political revolutions (e.g., The Great French Revolution) or the creation of new methods for the use of existing means of warfare (e.g., the "blitzkrieg") ${ }^{18}$. However, despite various factors which cause military revolutions, it is important to note that all revolutions in military affairs are united by the fact that new factors are implemented by new warfare doctrines (warfare strategy) and corresponding new force structures.

Taking the above ideas into consideration, the fundamental military change is defined by the invention of a new mode of warfare that may be conditioned by the implementation of a new technology, significant social transformations or innovative use of existing warfare instruments; and which can challenge the most powerful states of the international system, which do not wish to put their security under threat or to be deprived of influence on other subjects of international system. The concepts of the fundamental military change and revolution in military affairs in this article are used as synonyms. ${ }^{19}$

\footnotetext{
${ }^{17}$ Hundley R.O., Past Revolutions. Future Transformations. What can the history of revolution in military affairs tell us about transforming the U.S. military?, National Defense Research Institute, RAND, 1999, http://www.rand.org/pubs/monograph_reports/2007/MR1029.pdf, 1509 2008. Note: the factor of social/ economic/political transformations is distinguished by author.

${ }^{18}$ The military strategy applied by Germany during the World War II.

${ }^{19}$ The concept of the military-technical revolution is narrower than the concept of the fundamental military change because it concentrates only on one of the possible factors of the appearance of fundamental military change (although there are more of them). Meanwhile, the concept of the military change marks the fundamental reform of the military forces which is unnecessarily affected by the fundamental military change.
} 


\subsection{Interaction between the fundamental military change and the international system}

According to Michael Roberts, "the military revolution, indeed, had important effects upon international relations and international law. There can be no doubt that the strengthening of the state's control of military matters did something to regularize international relations. The mediaeval concept of war as an extension of feud grows faint; military activities by irresponsible individuals are frowned on; the states embark on the suppression of piracy $[\ldots]^{\prime \prime} .^{20}$

However, in order to estimate the influence of the fundamental military change on the international system, it is necessary to take into account the stages of "existence" of this change as its impact on international relations may vary during different phases of its cycle. Such stages are defined as the phases of the cycle of fundamental military change.

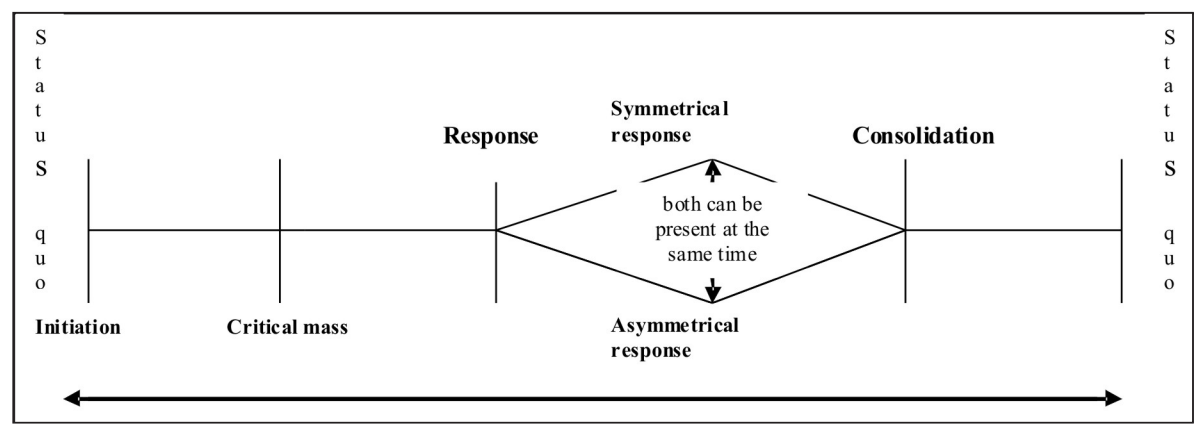

Figure 2. The cycle of the fundamental military change ${ }^{21}$

According to Steven Metz and James Kievit, the cycle begins with the phase of "initiation" as one state (e.g., the Mongol Empire in the times of Genghiz Khan or France in the times of Napoleon) or a group of states (the European states in the $19^{\text {th }}$ century) makes a step towards the fundamental military change. The fundamental military change enters the phase of "critical mass" as new modes of warfare are created on the basis of new technology or doctrinal/organizational innovations. Just after entering the phase of "critical mass", the fundamental military change receives international response which may be symmetrical (for example, the USSR after the defeats on land in 19411942 took over the methods of the operations on land carried out by German Wehrmacht) or asymmetrical (Mao's People's War, essentially the guerrilla war). The end of the "response" phase indicates that the subjects of the internatio-

\footnotetext{
${ }^{20}$ Roberts M., "The Military Revolution, 1560-1660" in Rogers C.J., ed., The Military Revolution Debate: Readings on the Military Transformation of Early Modern Europe, Colorado: Westview Press, 1995, p. 27.

${ }^{21}$ Metz S., Kievit J., Strategy and the Revolution in Military Affairs: From Theory to Policy, Strategic Studies Institute, 1995, http://www.au.af.mil/au/awc/awcgate/ssi/stratrma.pdf, 20092008.
} 
nal system developed appropriate symmetrical and asymmetrical means and adjusted to the fundamental military change. When balance between the main military powers is achieved, a status quo phase follows which is then broken by a new fundamental military change.

Taking into consideration the distinguished development cycles of the fundamental military change, one may maintain that the analysis of the influence of the fundamental military change on international relations during its different cycle phases enables one to provide thorough explanations about the impact of the fundamental military change on international relations.

\subsection{The offense-defence balance theory: the significance of the military change to international relations}

Although the offense-defence balance theory is just one of the theoretical approaches that can be used to explain the influence of the military factor on international relations, however, it is considered to be the only theory of international relations, which uses the military change as the main instrument to explain the state of international relations. The main postulate of this theory is that international conflicts and wars are more plausible at times when the offense ${ }^{22}$ has superiority; meanwhile, peace and cooperation are more possible when the superiority is on the side of the defence. According to R. Jervis, the superiority of the offense enhances the capacity to annihilate the enemy's army and to occupy its territory more quickly than to defend one's own. Whereas the superiority of the defence helps to defend oneself rather than to move forward, annihilate and occupy the enemy's territory. ${ }^{23}$ A relative consensus in this theory is the proposition that the military changes, which increase the mobility of forces, also strengthen the offense, while military innovations which increase the firepower are more favourable for the defence. ${ }^{24}$

Therefore, after the occurrence of military innovations, which are more favourable for the offense, it is possible to foresee that more wars will break out in the international system, which may lead to the formation of vast political units (empires); whereas, military innovations that are more favourable for the defence may result in less conflicts and may help the states retain independence and enhance mutual cooperation. According to Stephen Van

\footnotetext{
${ }^{22}$ The representatives of this theory generally use the notion of offense and defence to refer to the affectivity of arms used against other arms. The fixed (immobile) arms strengthen the defence; the mobile arms make the offense superior. See: Quester G.H., "Offense and Defence in the International System" in Brown M.E., Cote O.R. Jr., Lynn-Jones S.M., Miller S.E., ed., Offense, Defence, and War: An International Security Reader. London: The MIT Press, 2004, p. 54.

${ }^{23}$ Jervis R., "Cooperation under the Security Dilemma", in Brown M.E., Cote O.R. Jr., Lynn-Jones S.M., Miller S.E., ed., Offense, Defence, and War: An International Security Reader. London: The MIT Press, 2004, p. 23.

${ }^{24}$ Lieber K.A., "Grasping the Technological Peace: The Offense-Defence Balance and International Security" in Brown M.E., Cote O.R. Jr., Lynn-Jones S.M., Miller S.E.., ed., Offense, Defence, and War: An International Security Reader. London: The MIT Press, 2004, p. 373.
} 
Evera, one of the founders of the offense-defence balance theory, the superiority of the offense implies that the states are more likely to pursue aggressive foreign policy, to use "windows of possibility" and to wage preventive wars. However, the offense-defence balance theory draws attention to the fact that the superiority of the offense or the defence may be misjudged by political leaders. For example, the leaders of the European states worshipped the Cult of Offense in 1914, completely ignoring the power of the defence - this in its turn led to the World War I. ${ }^{25}$

However as one could expect, the offense-defence balance theory received some criticism. Among the more important arguments of the critics were: 1) the main independent variable of the theory (offense-defence balance) was not clearly defined; 2) the offense-defence balance cannot be measured, because the consequences of war are very unclear (i.e., the war may not necessarily start when the superiority is on the side of offense);3) military innovations which provided an opportunity to strengthen the mobility of forces did not always give superiority to the offense, and military innovations which strengthened the firepower did not always give superiority to the defence; 4 ) it is particularly complicated to attribute some historical periods to the times, when exclusive domination of the offense or the defence persisted. After trying to divide the period of 1495-1945 (encompassing 450 years) into the periods of exclusive dominance of the offense or the defence, consensus was found only regarding four different periods which encompass 185 years (two periods were dominated by the offense and the other two - by the defence). ${ }^{26}$

In response to the criticism some proponents of the offense-defence balance theory presented a more accurate definition of the offense-defence balance: "[...] as the ratio of the cost of the forces that the attacker requires to take territory to the cost of the defender's forces." 27 Taking into consideration the fact that the proportions of the offense-defence building costs may fluctuate due to other significant factors, propositions were made to include such factors as the number of forces, the accumulation of resources, nationalism, technology and geography into the offense-defence balance calculations. ${ }^{28}$ It has to be admitted that there was a proposition to exclude the behaviour of alliances and the first-move advantage ${ }^{29}$ from the offense-defence balance calculations. The behaviour of alliances, according to Charles L. Glaser and Chaim Kaufmann,

\footnotetext{
${ }^{25}$ Evera S.V., "The Cult of Offensive and the Origins of the First World War Security" in Brown M.E., Cote O.R. Jr., Lynn-Jones S.M., Miller S.E., ed., Offense, Defence, and War: An International Security Reader. London: The MIT Press, 2004, p. 69-118.

${ }^{26}$ Levy J.S., "The Offensive/Defensive Balance of Military Technology: A Theoretical and Historical Analysis", International Studies Quarterly (1984) 28, p. 234. The periods under the domination of offense were 1495-1525 and 1790-1815, and the defence dominated in 1650-1740 and 1850-1890.

${ }^{27}$ Glaser C.L., Kaufman C., „What is the Offense-Defence Balance and Can We Measure It?“ “ in Brown M.E., Cote O.R. Jr., Lynn-Jones S.M., Miller S.E., ed., Offense, Defence, and War: An International Security Reader. London: The MIT Press, 2004, p. 268.

${ }^{28}$ Ibid., p. 283-290.

${ }^{29}$ This term is used instead of "first-move strike" because the conflict is not only caused by the strike per se, but also by other factors (e.g., the mobilization, the drawing of forces closer to the border), which can act as the strike itself.
} 
increases the success of offense in such a way that it cannot be calculated by the offense-defence balance. The variable of the "first-move advantage" does not conform to the logic of the offense-defence balance because this advantage is never one-sided: both sides of the potential conflict may have some reasons to undertake actions that can lead to conflict.

All of the discussions on the offense-defence balance theory implicate the existence of at least two main trends of the interpretation of this theory. The first trend is a general one, which concentrates on the general interpretation of the condition of international relations based on the domination of offense or defence during a certain period; meanwhile, the second trend seeks to interpret the conflict between two states according to clear criteria which determine the offense-defence balance. Despite the criticism, the insights of the offensedefence balance theory are considered to be significant. The offense-defence theory gave grounds to the analysis and estimations of both the significance of military change to interstate relations and the development and condition of the international system itself. It is obvious, however, that the estimation of every historical period (based on the military change as the main variable of the interpretation) must be based not only on the calculation of the offense-defence balance, but also on the context of the period analyzed, whether political, social or cultural. Colin S. Gray reminds: "'context, context, context' decodes the origins, meaning, character and consequences of warfare" ${ }^{\prime 30}$.

Although the offense-defence balance theory does not aim to link the domination of offense or defence during various historical periods with fundamental military change but, on the other side, it gives a perspective of interpretation of the influence of the fundamental military change on the international system based on the characteristics of the change that has occurred. In other words, if we recognize new possibilities provided by the military change after the Cold War to execute offensive operations, which cannot be stopped with the existing measures of defence, then we can assume that the state at the forefront of the military change will be more often determined to apply military measures when solving political problems, thus, it is likely that a greater tension and bigger conflicts will arise in the international system.

\section{The impact of fundamental military change on the international system: the assessments of different historical periods}

The impact of every fundamental military change on the international system is strongly dependent on the analyzed historical period. The context of the analyzed historical period (social and political) is often the determinant

${ }^{30}$ Gray C.S., Another Bloody Century: Future Warfare, London: Phoenix, 2005, p. 55. 
factor. It is possible to distinguish many historical periods during which the influence of the military change on the international system manifested itself in different forms, however, in order to define the impact of the fundamental military change on the international system two different historical periods with essentially different consequences of the impact of the military change may be distinguished, i.e., the pre-nuclear era and the nuclear era. The main criterion of such distinction is the consequence of the impact of the fundamental military change on the dominant states of the system (i.e., whether the dominant state(s) of the system face the real threat of extinction or not). Today it would be too early to claim that it is possible to distinguish the third period which followed the Cold War, because the military progress of this period has not yet provided states with unique military instruments that could be used for defeating the nuclear states during a military conflict and preventing the threat of becoming a target of a nuclear strike. Otherwise, this does not put obstacles for further research on the influence of military change on the international system after the Cold War.

Taking into consideration the limited capacities of this paper to discuss various historical episodes from the pre-nuclear epoch in greater detail, two distinctive historical periods will be analyzed - the first part of the $15^{\text {th }}$ century (the artillery revolution) and the $16^{\text {th }}-17^{\text {th }}$ centuries (the naval revolution which coincided with the mastering of firearms), which reveal the dilemma of survival in the international system due to the influence of the fundamental military change and the exclusive opportunities to transform the hierarchy of dominant states.

\section{1. "To survive or to dominate": the determinant role of the fundamental military change in the pre-nuclear era}

\subsubsection{The consequences of the artillery revolution}

Until the period of 1400-1430, when interdependent military innovations $^{31}$ turned the field artillery into a threatening element of military power, cannons had been used for around hundred years in the wars of the medieval Europe but did not cause major military impact. Before the artillery revolution the medieval military fortification $\mathrm{s}^{32}$ were capable of withstanding long sieges. For example, the siege of Rouen during the Hundred Years' War lasted from 31 July, 1418 until 19 January, 1419, however, although the Englishmen intensively used bombards, the city surrendered because of the long-lasting famine and not because of the damage caused by the artillery. ${ }^{33}$ The artillery revolution became

\footnotetext{
${ }^{31}$ The newly invented cannons could bear bigger barrels (this increased the firepower, accuracy and speed); the cannon loading mechanism and powder formation was also improved.

${ }^{32}$ They were vertical because the aim was to provide protection not from the artillery bombardments but from the storm of the enemy's live force.

${ }^{33}$ Rogers C.J., „The Military Revolutions at the Hundred Years War“ in Rogers C.J., ed., The Military Revolution Debate: Readings on the Military Transformation of Early Modern Europe, Colorado: Westview Press, 1995, p. 6.
} 
a really expensive military innovation: in 1442 the expenditures of the French king for the "artillery trains" were twice as high as for the traditional military means such as bows, arrows, and lances. ${ }^{34}$ This negatively affected the capacity of smaller states to defend against larger states: up until this revolution the military forces of minor states could safely retreat into the fortified cities and castles, although they were incapable of fighting with the significantly stronger enemy in the open battlefield. The artillery revolution ensured a determinant superiority for larger and financially stronger states against smaller ones. The collapse of Siena as an independent state in the $16^{\text {th }}$ century after the French and Spanish invasions proved that the state was incapable of adjusting to the military changes caused by the artillery revolution. The success of France in winning back Normandy and Aquitaine in 1449-1453 and in pushing England out of France (the continent), thereby eliminating the most significant achievements of England in the Hundred Years' War, is a direct consequence of the artillery revolution..$^{35}$ The French rulers were not only able to change the course of the Hundred Years' War with England, but also to speed up the centralization of the state (Burgundy and Brittany also soon fell under the control of the French king). Simultaneously, Spain also used the military instruments provided by the artillery revolution and in 1482-1492 it managed to significantly weaken the positions of the Moors in the kingdom of Granada. Besides, the artillery revolution also hastened the fall of Constantinople and the Byzantine Empire in 1453. The impact of the artillery revolution was tangible until around 1525, when the Italian states stopped ${ }^{36}$ the Habsburgian onslaught in Italy thanks to the new military innovations - a construction of so-called trace italienne - which could withstand massive bombardment of fortifications. ${ }^{37}$

The artillery revolution provided an opportunity to temporarily change the power relations in the medieval Europe (Italian states vs. France or Spain; France vs. England during the war on the continent) or even to ruin the states (Siena, the Byzantine Empire). This military innovation was obviously more favourable to larger states, and unbalanced relations among relatively weaker and stronger states were 'reconstructed' only during the next military innovation. Therefore it is possible to presume that the consequences of the artillery revolution for interstate relations and for the entire state system of the medieval Europe would have been even more obvious if the representatives of Italy and other states had not managed to invent and construct fortifications that were able to withstand artillery bombardments.

\footnotetext{
${ }^{34}$ Ibid., p. 74.

${ }^{35}$ Goldman E.O., Andres R.B., ,Systemic Effects of Military Innovation and Diffusion “, Security Studies, Summer 1999, vol. 8, no. 4, p. 79-125, http://www.au.af.mil/au/awc/awcgate/innovation/jciss/syst.htm, 10022009.

${ }^{36}$ The state of Siena also planned to build the trace italienne, but did not have time to do it.

${ }^{37}$ Leon Battista Alberti, Italian architect and humanist, is considered to be the author of the idea of trace italienne.
} 


\subsubsection{Combination of the firearms and naval revolutions: the preconditions of the early global domination of the West}

The appearance of heavily-armoured sailing ships in the period of 14501650 radically transformed the then global situation. Until the first half of the $15^{\text {th }}$ century galleys driven by oars dominated in the European waters (the Mediterranean Sea, the seas bordering the Western coasts of France, Spain and Portugal, the shores of England and the Netherlands). However, around the middle of the $15^{\text {th }}$ century the oar-driven galleys were challenged by galleasses (the ships heavier than galleys with cannons fixed in the decks) and galleons (the ships driven by sails) armoured with cannons (fixed below the boat deck level). The appearance of heavy ships was mainly due to the artillery revolution that helped greatly increase the firepower and accuracy of cannons. The European powers (Spain, Portugal, England, the Netherlands, France, and Venice), which competed for domination in Europe and which aimed to control the global sea trading routes, quickly learned how to master these changes. This revolution was particularly painful for the Ottoman Empire which had until then dominated in the Mediterranean Sea, and whose navy of galleys was defeated by the Venetian galleasses in the battle of Lepant in 1571. The victory of the English navy against the Spanish Armada in 1588 marked another stage of the naval revolution, during which cannons capable of producing constant firepower were introduced. Just a few warships of the Spanish Armada were capable of keeping constant cannonade during the battle, and that determined the final victory of the English Navy. ${ }^{38}$ The frigate, which was constructed by the Dutch in the first half of the $17^{\text {th }}$ century and which could be ideally used for long distance voyages and battles, is considered to mark yet another stage of the naval revolution. ${ }^{39}$ Such competition among the European powers, which were able to quickly adapt to each other's military innovations, did not ensure absolute superiority to any of them in the short-term struggle against one another. However, the above mentioned military innovations together with the tactical revolution, defined by Michael Roberts during the $16^{\text {th }}$ century, provided Europe with exclusive military superiority against the civilizations of American ${ }^{40}$ and African continents, the populations of India and South Asia. Heavy marine vessels enabled the Western Europeans to conquer sea-trading routes in the Atlantic and Indian Oceans and also to project their power on land. The Europeans seized the main seaports and sea-trading routes, and they also managed to prevent the local states from challenging their domination in the coastal territories. Only the Far Eastern states (China and Japan) could seriously resist the Western European invasion into their territories, where Europeans established themselves only after the Industrial Revolution.

\footnotetext{
${ }^{38}$ Parker G., The Military Revolution: Military Innovation and the rise of the West, 1500-1800, Cambridge: Cambridge University Press, 1999, p. 95.

${ }^{39}$ Ibid., p. 99.

${ }^{40}$ The classical example would be the victories of Cortés over the Aztec Empire in 1519-1521.
} 
Taking into consideration the impact of these military innovations, it is possible to state that in the Western Europe these innovations were influenced by (emerged because of) the competition of the states, while aiming to control the sea-trading routes and while seeking to gain an overall superiority of power against the nearest rivals. However, on the other hand it is impossible to forget that the latter military innovations did not directly result from the competition among the rival states. The appearance of Venetian galleasses is linked with the intention of the Venetian rulers to protect their merchant navy from frequent pirate attacks in the Mediterranean Sea, but not with the power to compete against the Ottoman Empire or the European power. ${ }^{41}$ It is also important to mention that due to the navigation peculiarities at the Mediterranean Sea the galleys did not lose their significance at this sea until the $18^{\text {th }}$ century, but from the military point of view they were worthless in the open oceans. Nonetheless, the significance of the naval innovations of the $16^{\text {th }}-17^{\text {th }}$ centuries was that they enabled Western Europeans to conquer the global sea-trading routes and established conditions to expand the Western domination over other civilizations in the $19^{\text {th }}$ century.

\subsection{Military innovations during the Cold War: formation and maintenance of fragile strategic stability}

There are different opinions in the academic circles regarding the number of revolutions in military affairs that took place during the Cold War. However, there seems to be more consensus regarding the nuclear and aircraft carrier revolutions..$^{42}$ The invention of the nuclear weapon and later the test of the hydrogen bomb in 1952 created an entirely new warfare dimension among the states. Meanwhile, the appearance of the aircraft carriers changed the face of the conventional war at sea.

The nuclear revolution essentially changed the logic of the confrontation among the most powerful military states. Until the appearance of the nuclear weapon, the dominant military powers, which conflicted among themselves, could try to solve their discords in the battlefield. The appearance of the arsenal of nuclear and hydrogen bombs in the armoury of the US and the USSR, however, had de facto constrained the intention to escalate the mutual conflict.

\footnotetext{
${ }^{41}$ Parker G., The Military Revolution: Military Innovation and the rise of the West, 1500-1800, Cambridge: Cambridge University Press, 1999, p. 87.

${ }^{42}$ The proponents of the revolution in military affairs caused by aircraft carriers state that the war of aircraft carriers created a new operational and tactical level of war at sea; moreover, the accurate fire of warship fleets became unimportant. (Hundley R. O., Past Revolutions. Future Transformations. What can the history of revolution in military affairs tell us about transforming the U.S. military?, National Defence Research Institute, RAND, 1999, http://www.rand.org/pubs/monograph_reports/2007/MR1029.pdf, 1509 2008). On different opinions regarding military revolutions during the Cold War, see: Bernard S., "The Revolution in Military Affairs: The Approach with Caution", The Army Doctrine and Training Bulletin, Winter 2000/ Spring 2001, Vol.3, No. 4/ Volume 4, No.1, p. 60.
} 
Nevertheless, this conclusion, which is often repeated as a widely accepted truth, became a matter of fact only around 1972. Until then the confronting superpowers - the US and the USSR - felt vulnerable because of the continuous process to achieve a first nuclear strike advantage. Lawrence Freedman notes that in the late 1950s there was a belief that the rapid technological progress will be by itself destabilizing. ${ }^{43}$ It was assumed that the rapid technological leap could provide one of the confronting sides with the first strike advantage, which would deny the enemy to respond with a nuclear strike, too. The construction of intercontinental missiles capable of carrying nuclear warheads or the defence build up against long-range bombers were perceived as strengthening the first nuclear strike advantage.

In the middle of the 1960s, after the Cuban crisis, both the US and the USSR understood that neither of them had significant superiority in case of a nuclear conflict, but academics estimated that such a perception may be affected by the creation of an effective anti-missile defence system. ${ }^{44}$ The then US secretary of Defence Robert McNamara raised this question in the conversations with the Prime Minister of the USSR Alexander Kosygin (in 1967), but at that time the USSR government rejected the US proposal to stop the development of the anti-missile defence system, claiming that this measure could strengthen the defensive power. ${ }^{45}$ However, the Soviet Union soon recognized a potentially destabilizing effect of the anti-missile defence system to strategic stability and thus in 1972 the USSR together with the US signed a treaty, which limited the development of anti-missile defence system and their components. Although the strategic stability was maintained thanks to this agreement, soon this stability was repeatedly threatened as the relations between the US and the USSR worsened after the USSR invasion to Afghanistan and the dislocation of the US short-range and medium-range missiles in Western Europe in the early 1980s. In the course of such events, the US declared the Strategic Defence Initiative, the implementation of which would have been resulted with the creation of the modern anti-ballistic missile system. Even though the goals of the Strategic Defence Initiative were not achieved, the Soviet Union in response to this initiative spared a lot of time constructing symmetrical and asymmetrical measures.

The creation of aircraft carriers and the formation of carrier battle groups, which was considered as the fundamental military change, were not as significant as the aspiration of the US and the USSR to gain superiority in mutual confrontation while developing nuclear weapons as well as their launch and protection means. Nevertheless, the Soviet Union regarded the US

\footnotetext{
${ }^{43}$ Freedman L., "The First Two Generations of Nuclear Strategists" in Paret P., ed., Makers of Modern Strategy from Machiavelli to the Nuclear Age, Princeton: Princeton University Press, 1986, p. 755.

${ }^{44}$ For estimations of Herbert York and Jerome Wiesner, see: Freedman L., "The First Two Generations of Nuclear Strategists" in Paret P., ed., Makers of Modern Strategy from Machiavelli to the Nuclear Age, Princeton: Princeton University Press, 1986, p. 757.

${ }^{45}$ Kokoshin A.A., Nuclear Conflict in the Twenty-First Century, BCSIA Discussion Paper 2007-03, Kennedy School of Government, Harvard University, April 2007, http://belfercenter.ksg.harvard.edu/files/ kokoshin_2007_03.pdf, 20102008.
} 
carrier battle groups as a military measure of a huge threat and thus developed responsive measures in order to neutralize this threat. In the beginning, the Soviets planned to use the swarming attacks by bombers launching anti-ship missiles at long range. In response the US constructed and implemented the Aegis system. Soviets reacted to this military innovation by creating a Sunborn missile, capable of very-low-level supersonic flight. ${ }^{46}$

In order to estimate the significance of the nuclear revolution in regards to international relations, it is important to note several aspects. This military innovation for the first time in history has limited the intention of the confronting states of the system to solve conflicts by military measures, because of the threat of mutual annihilation. However, the real effect of such limitation (strategic stability) was continuously tested by new military innovations that could give one or the other side assurance of its superiority in case of a nuclear war. The impact of the formation of carrier groups should probably be regarded as a temporal increase of tension between the US and the USSR which did not make a significant impact.

\subsection{US military transformation after the Cold War: implications to strategic stability of international system}

The influence of military change on international relations after the Cold war can be assessed based on the conditional distinction of two periods. During the first period (till the escalation of conflicts in Iraq and Afghanistan in years 2005-2006) a belief in military progress was dominant among the US leaders. Then followed a period marked with the increasing doubts on the revolution in military affairs phenomenon after the Cold war, and the possible imaginable advantages for the Americans themselves.

The beginning of the first period is associated with the successful US-led military operation against Iraq in 1991. The first expanded use of the PGMs ${ }^{47}$, the JSTARS $^{48}$ and the satellite-based GPS in this operation stimulated the Pentagon analysts ${ }^{49}$ to proclaim the contemporary revolution in military affairs. Some US military officers were so convinced by the power of the PGMs that they started to question the utility of land forces in the Iraq war, and potentially in future conflicts as well. ${ }^{50}$ Radical proponents of contemporary revolution in military affairs, such as US admiral William Owen, forecasted future American military superiority, which will rely on the "system of systems" to be created

\footnotetext{
${ }^{46}$ Alach Z. J., Slowing Military Change, Strategic Studies Institute, October 2008, p. 25-28, http://www. strategicstudiesinstitute.army.mil/pdffiles/pub878.pdf, 03042009.

${ }^{47}$ PGMs amounted only to about 10 percent of the weapons used in this military operation. Benbow T., The Magic Bullet: Understanding the Revolution in Military Affairs, London: Brassey“s, 2004, p. 71.

${ }^{48}$ Joint Surveillance and Targer Attack Radar System

${ }^{49}$ Analysts at the Office of Net Assessments in the Defence Department, led by Andrew Marshall.

${ }^{50}$ Benbow T., The Magic Bullet: Understanding the ,Revolution in Military Affairs, London: Brassey's, 2004, p. 66.
} 
with the support of the newest information technologies. ${ }^{51}$ Such a revolution in military affairs will make US Armed Forces undefeatable in the typical conventional military conflict. ${ }^{52}$ Proponents of the revolution in military affairs were convinced that achieved military progress in the end of the day will even deny fundamental "fog of war" thesis developed by Carl von Clausewitz. US Armed Forces Joint Vision 2010, released in 1996, reflected approach of the proponents of the revolution in military affairs, which indicated the US dominance in all possible types of conflicts due to the information technologies.$^{53}$ Initiated military transformation of the Americans was targeted not just to enhance the PGMs capabilities (basically related with the Air Force) but to expand potential of the Land Forces to execute successful operations (for example projects The Army After Next, Future Combat System). Although in 1999, the US made some corrections in the military transformation project (not only the "digitization" of the Armed Forces but expansion of the deployability capabilities of the Land Forces $^{54}$ ) the main assumptions of the military transformation were to stay in power. New US president G. W. Bush and his defence secretary D. Rumsfeld were firm supporters of the US military transformation programme based on the revolution in military affairs ideas. G. W. Bush and D. Rumsfeld in their military transformation vision saw U.S. Armed Forces to be rapidly deployable, reaching the furthest distances and defeating opponents exactly there ${ }^{55}$ Accordingly the US defence planning process was reoriented along the lines of the this vision: the threat based defence planning process was replaced by the capabilities based defence planning, which seemed to enable for a preparation to counter any possible threat.

However, the course of the conflicts in Iraq and Afghanistan signalled to US political leaders the limits of the mobile and deployable Armed Forces, even if built on the newest information technologies. It is acknowledged that the transformation of the US conventional military forces has been one of the key success factors for the military operations in Iraq and Afghanistan. US Special and the Air Force, enabled by the information technologies could act in such a coordinative manner, which was never seen before. During the Operation

\footnotetext{
${ }^{51}$ Systems: 1) sensors; 2) command and control based on the advanced computer technologies; 3) knowhow of the exploitation of information Žr. Benbow T., The Magic Bullet: Understanding the ,Revolution in Military Affairs, London: Brassey‘s, 2004, p. 80-81; Kagan F.W., Finding the Target: The Transformation of American Military Policy, New York, London: Encounter Books, 2006, p. 217.

${ }^{52}$ Conventional conflict is a conflict where nuclear weapons are not used and where no one party in the conflict doesn't rely only on the partisan war methods and techniques.

${ }^{53}$ Joint Vision 2010 indicates: "[...] Long-range precision capability, combined with a wide range of delivery systems, is emerging as a key factor in future warfare [..]" Joint Vision 2010, Office of the Joint Chiefs of Staff, 1996 http://www.dtic.mil/jv2010/jv2010.pdf, 20052009.

${ }_{54}^{54}$ Programme of the U.S. Chief of Joint Staff gen. Eric Shinseki.

${ }_{55}$ Rumsfeld D., 21st Century Transformation, National Defence University, Fort McNair, Washington, D.C., Thursday, January 31, 2002, http://www.defenselink.mil/speeches/speech.aspx?speechid=183, 1002 2009. Donald Rumsfeld conception indicates that US major forces have to be capable for deployment to a distant theatre in 10 days, defeat the enemy within 30 days and then be ready for redeployment somewhere else within another 30 days. Hawkins W. R., Is Rumsfeld's "Revolution in Military Affairs" Finally Over?, http://www.americaneconomicalert.org/view_art.asp?Prod_ID=2548, 10022009.
} 
Iraqi Freedom US military could find the target and launch the PGMs in ten minutes, while during the Operation Desert Storm such action could last up to three days ${ }^{56}$ However, a hardly fought insurgency in Iraq and Afghanistan by America stimulated a different view on the results of the military transformation, which recognized the limits of transformed conventional forces to fight the dispersed enemy who is not fighting America like the regimes of Saddam Hussein or Taliban did. It is obvious that the US political and military leadership, when planning military operation against Iraq in 2003, was expecting that the conventional offensive with a capture of Baghdad at the end, would be the decisive factor for the success. However, the insurgency led by the Sunnis in April-May of 2003 in Iraq proved that the conventional military superiority is not the strategic political pre-eminence. Afghanistan conflict also showed that the overthrow of the Taliban regime gives no guarantee for the victory against the Al-Qaeda and its supporters.

Insurgency in Iraq and Afghanistan convinced US leaders (President G. W. Bush in his second term and new President B. Obama) about the limits of military decisions (even if backed by the most modern military forces) to broker political stalemates: the changed US strategy in Iraq in 2006/2007, the new Afghanistan-Pakistan strategy announced by the US President B. Obama devoted more attention to political instruments. But the US military capabilities development process is not blindly resting on the President G. W. Bush's vision anymore. Balanced strategy declared by the US defence secretary Robert M. Gates exactly points an overwhelming need to balance the demands to win the current wars and be prepared for the future conflicts. In addition this strategy foresees to balance the institutionalization of counterinsurgency capabilities and to maintain the United States' existing conventional and strategic technological edge against other military forces. ${ }^{57}$ However, it is evident that the Balanced strategy of defence secretary Robert M. Gates continues to stress the fundamental need to maintain military superiority against anyone, which was so typical in the rhetoric of the former US President G. W. Bush. It seems that the military transformation may further act as a strong motivation for the US leaders to rely primarily on the military instruments when solving the conflicts.

The direct impact of the US military transformation for the other actors in the international system is a different one. US allies (for example NATO members and Australia) try to adapt some of the US military transformation elements as to stay (operationally) relevant in the upcoming possible joint

\footnotetext{
${ }^{56}$ Boot M., War Made New: Weapons, Warriors, and the Making of the Modern World, New York: Gotham Books, 2006, p. 355-357, 397. Also look at Biddle S., Embrey J., Filiberti E., Kider S., Metz S., Oelrich I. C., Shelton R., Toppling Saddam: Iraq and American Military Transformation, April 2004, http://www.fas. org/man/eprint/biddle.pdf, 10022009.

${ }^{57}$ Gates R. M., "A Balanced Strategy: Reprogramming the Pentagon for a New Age”, Foreign Affairs, January/February 2009, p. 28-40. Also look at the Statement of General James N. Mattis, USMC Commander, United States Joint Force Command, House Armed Services Committee, March 18, 2009, http://www.jfcom. mil/newslink/storyarchive/2009/sp031809.html, 10082009.
} 
military operations with the US Armed Forces. ${ }^{58}$ However, the attitudes and reactions of the People's Republic of China and Russia (potential US opponents) to the US military transformation are differing. The People's Republic of China is concerned more about the influence of the US military transformation process to its goal reintegrate Taiwan, if needed by force..$^{59}$ Meanwhile Russia gives priority to maintain the capability for nuclear strikes considering the increased power of US conventional forces at the outcome of the military transformation process. ${ }^{60}$ It seems that the US military transformation is pushing Iran to acquire the nuclear strike capabilities too.

There are several important aspects to be drawn from the generalized assessment on the impact of the US military transformation to the contemporary international relations. Firstly, the military transformation encouraged the US leaders to rely more on the military power in the international relations. The importance of the military capabilities when solving strategic political problems was too much exaggerated. Secondly, the assumption supposing that the US military transformation acts as a trigger for other states to initiate and pursue their nuclear weapons programmes seems to gain more credibility. For such states as Iran the acquisition of nuclear weapon will give more sense of security vis-a-vis US than the mere modernization of conventional forces. Thirdly, the spread of the newest military technologies around the world (which are the core of US conventional military strength) weakens the US military superiority against the potential opponents. Andrew Krepinevich is certain that the US military domination is diminishing basically because of the loosing monopoly on the production of the precision-guided munitions. ${ }^{61}$ This trend may encourage the potential US opponents to test the US military power more often than in the past, which may result in the increasing instability and tension in the international system.

\footnotetext{
${ }^{58}$ Evans M., Australia and the Revolution in Military Affairs, Land Warfare Studies Centre: Working Paper 115, August 2001, http://www.defence.gov.au/army/LWSC/docs/wp\%20115.pdf, 2009 2008; Donnelly C., How Do Allies Deal With U.S. Military Transformation, NIDS Symposium on the International Security 2006. Military Transformation in the 21 st Century: Challenges for New Security Environment, http://www. nids.go.jp/english/dissemination/other/symposium/2006pdf/e2005_06.pdf, 2009 2008; Sloan E., "Canada and the Revolution in Military Affairs: Current Response and Future Opportunities", Canadian Military Journal, Autumn 2000, http://www.journal.forces.gc.ca/vo1/no3/doc/7-14-eng.pdf, 2009 2008; Sloan E., Military Transformation and Modern Warfare: A Reference Handbook, Westport, Connecticut, London: Praeger Security International, 2008.

${ }^{59}$ Mulvenon J. C., Tanner M. S., Chase M. S., Frelinger D., Gompert D. C., Libicki M. C., Pollpeter K. L., Chinese Responses to U.S. Military Transformation and Implications for the Department of Defense. RAND, 2006, http://www.rand.org/pubs/monographs/2006/RAND MG340.pdf, 20072009.

${ }^{60}$ Sloan E., Military Transformation and Modern Warfare: A Reference Handbook, Westport, Connecticut, London: Praeger Security International, 2008, p. 109-121.

${ }^{61}$ Krepinevich A. F., "The Pentagon's Wasting Assets: The Eroding Foundations of American Power”, Foreign Affairs, July/August 2009, Vol. 88, No. 4, p. 18-33.
} 


\section{Conclusions}

Analysis of the military change impact on international system presents one additional perspective to look at the processes in the international relations. However, such insights are directly dependent upon the solution of important methodological question - how to define the military change when we are looking for the precise and valid evaluation of its impact on international relations. So the construction of the fundamental military change concept is the main methodological point of departure, which helps to identify the research framework for the interactions between military change and international system analysis. The sceptics of such research should be aware of argument that this particular analysis is not inclined to evaluate the impact of all new and continuously discovered means of warfare on the international system if those do not change the dominant means and patterns of warfare. Unfortunately, it must be pointed out that the explanatory power of the offense-defence balance theory is suffering exactly because the used military change concept lacks clarity. On the other hand, the offense-defence balance theory is perfect in explaining the basic logic of the military change impact to international relations, which is valid in the analysis of different historical periods, and which can be adapted for contemporary international relations.

The analysis of three different historical periods (the Middle Ages and Modern Times, Cold War era, post-Cold War era) showed the possibility to identify the impact of fundamental military change, although the extent and results of such an impact are uneven. It must be pointed out that only the analyzed artillery, firearms, naval and nuclear revolutions can be labelled as the fundamental military change. The argument that the military change after the Cold War is a fundamental one becomes more and more loosely grounded. However, it is still too early to completely judge the military change after the Cold War: fundamental military changes are generally extended over a much longer period than the twenty year period that has passed since the end of Cold War. However, this is not an obstacle to assess the impact of military change (which nevertheless may still turn into a fundamental one) to contemporary international relations.

The logic of the impact of fundamental military during the Middle Ages and Modern times to the interstate relations is simple: a state, which was not capable to follow after the fundamental military change, faced a threat of extinction from the political map. During the Cold War era the nuclear weapon became a balancing factor of the international system, especially when monopoly of nuclear weapons was divided between two camps, the Soviet and the American. However, it is true some time was needed as both camps recognized the potential of the other side to initiate the first and the second nuclear strikes.

US military transformation after the Cold War became a factor, which destabilizes contemporary international relations. It is mainly because of the 


\section{Conclusions}

Analysis of the military change impact on international system presents one additional perspective to look at the processes in the international relations. However, such insights are directly dependent upon the solution of important methodological question - how to define the military change when we are looking for the precise and valid evaluation of its impact on international relations. So the construction of the fundamental military change concept is the main methodological point of departure, which helps to identify the research framework for the interactions between military change and international system analysis. The sceptics of such research should be aware of argument that this particular analysis is not inclined to evaluate the impact of all new and continuously discovered means of warfare on the international system if those do not change the dominant means and patterns of warfare. Unfortunately, it must be pointed out that the explanatory power of the offense-defence balance theory is suffering exactly because the used military change concept lacks clarity. On the other hand, the offense-defence balance theory is perfect in explaining the basic logic of the military change impact to international relations, which is valid in the analysis of different historical periods, and which can be adapted for contemporary international relations.

The analysis of three different historical periods (the Middle Ages and Modern Times, Cold War era, post-Cold War era) showed the possibility to identify the impact of fundamental military change, although the extent and results of such an impact are uneven. It must be pointed out that only the analyzed artillery, firearms, naval and nuclear revolutions can be labelled as the fundamental military change. The argument that the military change after the Cold War is a fundamental one becomes more and more loosely grounded. However, it is still too early to completely judge the military change after the Cold War: fundamental military changes are generally extended over a much longer period than the twenty year period that has passed since the end of Cold War. However, this is not an obstacle to assess the impact of military change (which nevertheless may still turn into a fundamental one) to contemporary international relations.

The logic of the impact of fundamental military during the Middle Ages and Modern times to the interstate relations is simple: a state, which was not capable to follow after the fundamental military change, faced a threat of extinction from the political map. During the Cold War era the nuclear weapon became a balancing factor of the international system, especially when monopoly of nuclear weapons was divided between two camps, the Soviet and the American. However, it is true some time was needed as both camps recognized the potential of the other side to initiate the first and the second nuclear strikes.

US military transformation after the Cold War became a factor, which destabilizes contemporary international relations. It is mainly because of the 
increased US reliance on the conventional military capabilities when solving strategic political problems such as a change of the Iraqi regime. In addition, the US military transformation even more encouraged hostiles towards the US states to acquire nuclear weapon, which might deter US conventional onslaught. Information technologies - the engine of the US military transformation, became widely used by other states and the terrorist groups (such as Al-Qaeda), making the US more vulnerable. Consequently, the hostiles towards the US actors are ready to exploit the emerging US weaknesses, and that in effect increase instability of the whole international system.

Excursuses into the historical periods (the Middle Ages and Modern times; the Cold War period), explaining the interaction between military change and international system, and analysis of the impact of US military transformation to contemporary international relations and the interpretations of such interactions show the importance of further studies in this field. It is even more relevant while still the military superiority is held one of the most reliable instruments to ensure national security.

Vilnius, April-September 2009 